\title{
Jancuk : Public perception on the use of swear words in Communication among Arek Cultural Community in East Java
}

\author{
Ahmadintya Anggit Hanggraito \\ Manajemen Bisnis Pariwisata, Politeknik Negeri Banyuwangi, Indonesia \\ Email: ahmadintya.anggithanggraito@poliwangi.ac.id
}

\begin{abstract}
Jancuk is a swear word and has become part of the cultural communication of arek in East Java, Indonesia. This research tries to analyze the perception and meaning of jancuk from Indonesian society. This research is descriptive research through a qualitative approach. 121 representative respondents were obtained through purposive sampling. Then, the data will be triangulated to draw conclusions and recommendations. The results showed that the period of education and growth became the jancuk word's absorption phase. The results of the analysis explain that Jancuk is not perceived negatively. Its depends on the intensity of emotion in communication. However, Jancuk is still perceived as a word that violates politeness in the communication process. Then, the main meaning of jancuk consists of: humiliation, annoyance, disappointment, surprise, and a symbol of intimacy or humor. Based on this research, the perception of words in a particular culture can be seen as an expression that has various meanings. It is expected that this research will provide the reason for the public that jancuk can be an important contributor to the process of enriching social cross-cultural communication materials.
\end{abstract}

Keywords: Jancuk; swear words; Cultural communication; Public Perception ; Meaning.

\begin{abstract}
Jancuk merupakan sebuah pisuban dan telah menjadi bagian dari komunikasi budaya arek Jawa Timur, Indonesia. Penelitian ini berusaha menganalisis persepsi dan pemaknaan jancuk dari masyarakat Indonesia. Penelitian ini merupakan penelitian deskriptif dengan pendekatan kualitatif yang mendapatkan 121 responden yang representatif melalui purposive sampling. Selanjutnya, dilakukan triangulasi data agar menghasilkan kesimpulan. Hasil Penelitian menunjukkan masa pendidikan dan bertumbuh menjadi fase penyerapan kata jancuk. Hasil analisis menunjukkan bahwa, jancuk tidak dipersepsikan secara negatif. Hal ini dikarenakan adanya ketergantungan terhadap intensitas emosi dalam komunikasi seseorang. Namun, Jancuk tetap dipersepsikan sebagai kata yang menyalahi tata krama dalam proses komunikasi. Kemudian, pemaknaan utama dari jancuk terdiri atas: penghinaan, kekesalan, kekecewaan, keterkejutan, dan simbol keakraban. Berdasarkan penelitian ini, persepsi terhadap kata dalam sebuah budaya tertentu dapat dilihat sebagai ungkapan yang memiliki berbagai pemaknaan. Penelitian ini diharapkan dapat memberikan justifikasi terhadap masyarakat bahwa, jancuk dapat menjadi kontributor penting dalam proses memperkaya materi komunikasi antar budaya dalam masyarakat.
\end{abstract}

Kata kunci : Jancuk; Pisuhan; Komunikasi budaya; persepsi masyarakat; makna

\section{A. PRELIMINARY}


As part of the Indonesian state, East Java has various cultural relationships related from one region to another that have diverse cultural expressions. One of the cultures in East Java is the Arek culture, where this culture is known as a character in East Java who lives in Surabaya, Sidoarjo, Mojokerto, Malang, Gresik, and a small part of it in Jombang and Pasuruan (Abdillah, 2007; Sriyanto and Fauzie 2017; Sungkowati 2019). The population of East Java until 2020 is $40,666,000$ people in 2010 with an average growth rate of $0.79 \%$ per year in the period 2010 to 2020 (Statistics of East Java Province, 2021). It is stated in detail that,

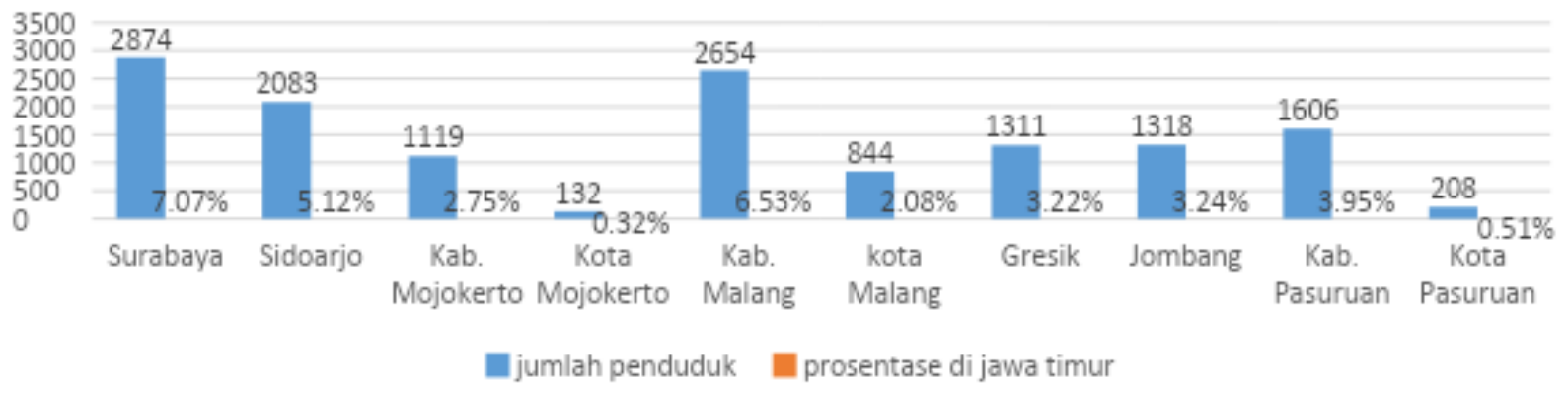

Source: Statistics of East Java Province (2021)

Figure 1. Population in the Arek cultural area in East Java in 2020

Based on Figure 1. There are about $34.79 \%$ of the total population of East Java who have the potential to have confirmed culture as a communicator of arek culture in East Java. Therefore, indirectly arek culture has an important role in shaping the process of intercultural communication in society in East Java.

Basically, according to Mulyana \& Rakhmat (2014) Intercultural communication bridges the differences between communicators and communicants of different cultures so that they are not isolated. (Sihwanti, 2019). Therefore, arek culture which is part of East Java has its own cultural treasures that can be preserved through the process of intercultural communication. The use of East Javanese arek culture when communicating with non-areek culture will produce two values, positive and negative. One of the communication media that is part of culture is language. Language is an organized communication tool in the form of units, such as words, groups of words, clauses, and sentences that are expressed both orally and in writing.(Wiratno \& Santosa, 2014). Sumarsono and Partana (2002), state that language has other social functions involved in formulas that consider language as the identity of speakers, both individually and in groups.(Jannah et al., 2018). There are various vocabularies that are part of the language of the East Javanese culture that can facilitate the communication process in a cultural interaction. In 
fact, the cultural language of East Java has a variety of types of words that are spoken when in the process of cultural communication, namely pisuhan.

Separationis something that can be encountered when someone shows certain emotions through cultural intermediaries. Pisuhan according to the Javanese Basa Dictionary or Javanese Bausastra (2001) is a rude tetembungan utawa tetembungan utawa pepoyok sing saru (words or harsh words or insults that are not polite)(Winiasih, 2012). Pisuhan is able to express various attitudes, including: 1) anger; 2) irritation; 3) regret; 4) sadness; 5) disappointment; 6) admiration or astonishment; 7) humiliation or demeaning of others; 8) surprise; 9) familiarity or sense of humor; and 10) joy(Winiasih, 2012). One of the word choices used in the East Javanese arek culture is jancuk. The word jancuk itself is famous for being saru (not appropriate to pronounce), but it is popular among the people of East Java, especially the cities of Surabaya and Malang(Sriyanto \& Fauzie, 2017). Tejo (2012) explains that, jancuk or commonly abbreviated as cuk has diversity in its use, with sincere intentions the use of the word jancuk can be used to establish intimacy between the speaker and the addressee, but if the use of the word jancuk with insincere intentions, then the word jancuk can hurt(Budiman et al., 2018). Therefore, theoretically Jancuk can appear in negative conditions through a bad attitude, and can also be channeled in positive situations which ultimately have an impact on extra closeness between close friends.

The existence of two distributions of the value of the word jancuk in a communication process will produce various functions and meanings. This depends on the behavior that is practiced by someone from within or from outside the Arek cultural area who uses the word jancuk. Jancuk is a choice of words from various pisuhan originating from the arek culture in East Java. Public perception of the word jancuk will show the value and meaning of a culture that is communicated through language. Perception, according to Schiffman \& Kanuk (2000), is the process of an individual in selecting, organizing, and interpreting stimuli into a meaningful and coherent picture of the world.(Pani, 2019). In fact, Indonesian people have a rich culture from one region to another with their respective interpretations. Therefore, people's perceptions of jancuk will produce various meanings that are able to represent variations in cultural concepts from different perspectives. This is a result of the intercultural interaction process of a group of people having various values, norms, systems which are finally communicated within a certain time. Based on the above background, this study aims to analyze the perceptions and meanings of Indonesian people related to jancuk. The benefit of this research is to be able to provide a structured understanding of the word jancuk as an important material in a process of communication for East Java's arek culture. 


\section{B. METHOD}

This research is descriptive research with a qualitative approach. Descriptive research is conducted to describe a set of symptoms or events from a population objectively.(Zellatifanny \& Mudjiyanto, 2018). Qualitative research seeks to identify ideographically various phenomena and social realities(Somantri, 2005). In this case, Jancuk as part of East Java's arek culture is trying to be explained through various quantitative data. These various data come from the perceptions and meanings of the community related to jancuk. This research uses purposive sampling using 121 samples that can represent the general public from various regions in Indonesia who have had direct contact with the word jancuk.

Quantitative data comes from the results of a questionnaire that has a representation of people's perceptions related to the word jancuk. Qualitative data in the form of article documentation and the results of respondents' opinions are embedded in several questions in the questionnaire. The first data analysis was done by analyzing descriptive statistics from the questionnaire results. This analysis is related to the summary description of research data such as mean, standard deviation, variance, mode(Soecahyadi, 2012). Furthermore, the results of the questionnaire were triangulated with various qualitative data that supported the statistics from the quantitative data. Triangulation is not aimed at finding the truth, but increasing researchers' understanding of the data and facts they have(Bachri, 2010). Furthermore, the understanding that emerged descriptively resulted in conclusions and recommendations.

\section{RESULTS AND DISCUSSION}

\section{Respondents' experience with the word Jancuk}

In general, the discussion of the word jancuk has been embedded in most levels of East Javanese society in Indonesia. In general, the word jancuk has a meaning with "jancok", "chock", or "chock". Therefore, a person or group of people will be able to show their attachment to the word Jancuk with various equivalent meanings. Sensing a person will respond to various situations around him. So that a person's experience related to jancuk will be obtained through his sight, hearing, feeling, and so on. The following are the statistics of respondents who have interacted directly with the word jancuk,

Table 1. Profile of respondents who have interacted with Jancuk

\begin{tabular}{ccccc}
\hline Variable & Category & Total & Man & Woman \\
\hline \multirow{2}{*}{ Gender } & & 121 & 65 & 56 \\
\cline { 2 - 4 } & & $100.0 \%$ & $53.7 \%$ & $46.3 \%$ \\
\hline
\end{tabular}




\begin{tabular}{|c|c|c|c|c|}
\hline \multirow{8}{*}{ Age } & \multirow{2}{*}{ 21-30 years old } & 58 & 24 & 34 \\
\hline & & $47.9 \%$ & $19.8 \%$ & $28.1 \%$ \\
\hline & \multirow{2}{*}{$31-40$ years old } & 52 & 34 & 18 \\
\hline & & $43.0 \%$ & $28.1 \%$ & $14.9 \%$ \\
\hline & \multirow{2}{*}{$41-50$ years old } & 10 & 6 & 4 \\
\hline & & $8.3 \%$ & $5.0 \%$ & $3.3 \%$ \\
\hline & \multirow{2}{*}{$>50$ years } & 1 & 1 & 0 \\
\hline & & $0.8 \%$ & $0.8 \%$ & $0.0 \%$ \\
\hline \multirow{8}{*}{$\begin{array}{l}\text { Time to } \\
\text { grow and } \\
\text { grow } \\
\text { (0-17 years) }\end{array}$} & \multirow{2}{*}{$\begin{array}{c}\text { Original Arek Budaya Cultural area } \\
\text { (Surabaya, Sidoarjo, Mojokerto, Malang } \\
\text { Raya, Gresik, Jombang and Pasuruan) }\end{array}$} & 51 & 31 & 20 \\
\hline & & $42.1 \%$ & $25.6 \%$ & $16.5 \%$ \\
\hline & \multirow{2}{*}{$\begin{array}{c}\text { East Java } \\
\text { (But apart from Surabaya, Sidoarjo, } \\
\text { Mojokerto, Malang Raya, Gresik, Jombang } \\
\text { and Pasuruan) }\end{array}$} & 11 & 5 & 6 \\
\hline & & $9.1 \%$ & $4.1 \%$ & $5.0 \%$ \\
\hline & \multirow{2}{*}{$\begin{array}{l}\text { From outside East Java (but still on the island } \\
\text { of Java) }\end{array}$} & 37 & 22 & 15 \\
\hline & & $30.6 \%$ & $18.2 \%$ & $12.4 \%$ \\
\hline & \multirow{2}{*}{ From outside Java (but still in Indonesia) } & 22 & 7 & 15 \\
\hline & & $18.2 \%$ & $5.8 \%$ & $12.4 \%$ \\
\hline \multirow{8}{*}{ Domicile } & \multirow{2}{*}{$\begin{array}{c}\text { Original Arek Budaya Cultural area } \\
\text { (Surabaya, Sidoarjo, Mojokerto, Malang } \\
\text { Raya, Gresik, Jombang and Pasuruan) }\end{array}$} & 36 & 21 & 15 \\
\hline & & $29.8 \%$ & $17.4 \%$ & $12.4 \%$ \\
\hline & \multirow{2}{*}{$\begin{array}{c}\text { East Java } \\
\text { (But apart from Surabaya, Sidoarjo, } \\
\text { Mojokerto, Malang Raya, Gresik, Jombang } \\
\text { and Pasuruan) }\end{array}$} & 9 & 5 & 4 \\
\hline & & $7.4 \%$ & $4.1 \%$ & $3.3 \%$ \\
\hline & \multirow{2}{*}{$\begin{array}{l}\text { From outside East Java (but still on the island } \\
\text { of Java) }\end{array}$} & 55 & 30 & 25 \\
\hline & & $45.5 \%$ & $24.8 \%$ & $20.7 \%$ \\
\hline & \multirow{2}{*}{ From outside Java (but still in Indonesia) } & 21 & 9 & 12 \\
\hline & & $17.4 \%$ & $7.4 \%$ & $9.9 \%$ \\
\hline \multirow{10}{*}{ Education } & \multirow{2}{*}{ Elementary/junior high/high school } & 5 & 3 & 2 \\
\hline & & $4.1 \%$ & $2.5 \%$ & $1.7 \%$ \\
\hline & \multirow{2}{*}{ Vocational } & 2 & 2 & 0 \\
\hline & & $1.7 \%$ & $1.7 \%$ & $0.0 \%$ \\
\hline & \multirow{2}{*}{ Bachelor degree) } & 76 & 42 & 34 \\
\hline & & $62.8 \%$ & $34.7 \%$ & $28.1 \%$ \\
\hline & \multirow{2}{*}{ Masters (S2) } & 37 & 18 & 19 \\
\hline & & $30.6 \%$ & $14.9 \%$ & $15.7 \%$ \\
\hline & \multirow{2}{*}{ Doctoral (S3) } & 1 & 0 & 1 \\
\hline & & $0.8 \%$ & $0.0 \%$ & $0.8 \%$ \\
\hline \multirow{7}{*}{ Work } & \multirow{2}{*}{ entrepreneur } & 20 & 14 & 6 \\
\hline & & $16.5 \%$ & $11.6 \%$ & $5.0 \%$ \\
\hline & \multirow{2}{*}{ PNS/BUMN/Government } & 25 & 13 & 12 \\
\hline & & $20.7 \%$ & $10.7 \%$ & $9.9 \%$ \\
\hline & \multirow{2}{*}{ Lecturer/Teacher/Lecturer } & 10 & 4 & 6 \\
\hline & & $8.3 \%$ & $3.3 \%$ & $5.0 \%$ \\
\hline & Health workers & 3 & 1 & 2 \\
\hline
\end{tabular}




\begin{tabular}{|c|c|c|c|c|}
\hline & & $2.5 \%$ & $0.8 \%$ & $1.7 \%$ \\
\hline & \multirow{2}{*}{ Private employees } & 30 & 16 & 14 \\
\hline & & $24.8 \%$ & $13.2 \%$ & $11.6 \%$ \\
\hline & \multirow{2}{*}{ Student/Student } & 12 & 8 & 4 \\
\hline & & $9.9 \%$ & $6.6 \%$ & $3.3 \%$ \\
\hline & \multirow{2}{*}{ Housewife } & 8 & 0 & 8 \\
\hline & & $6.6 \%$ & $0.0 \%$ & $6.6 \%$ \\
\hline & \multirow{2}{*}{ Freelancer } & 10 & 8 & 2 \\
\hline & & $8.3 \%$ & $6.6 \%$ & $1.7 \%$ \\
\hline & \multirow{2}{*}{ Journalist } & 1 & 0 & 1 \\
\hline & & $0.8 \%$ & $0.0 \%$ & $0.8 \%$ \\
\hline & \multirow{2}{*}{ Other } & 2 & 1 & 1 \\
\hline & & $1.7 \%$ & $0.8 \%$ & $0.8 \%$ \\
\hline \multirow{8}{*}{$\begin{array}{l}\text { First time } \\
\text { hearing the } \\
\text { word } \\
\text { "choke", } \\
\text { "choke", } \\
\text { "chock", } \\
\text { "chock" }\end{array}$} & \multirow{2}{*}{$<11$ years old } & 54 & 36 & 18 \\
\hline & & $44.6 \%$ & $29.8 \%$ & $14.9 \%$ \\
\hline & \multirow{2}{*}{$11-20$ years old } & 45 & 21 & 24 \\
\hline & & $37.2 \%$ & $17.4 \%$ & $19.8 \%$ \\
\hline & \multirow{2}{*}{ 21-30 years old } & 19 & 7 & 12 \\
\hline & & $15.7 \%$ & $5.8 \%$ & $9.9 \%$ \\
\hline & \multirow{2}{*}{$31-40$ years old } & 3 & 1 & 2 \\
\hline & & $2.5 \%$ & $0.8 \%$ & $1.7 \%$ \\
\hline \multirow{14}{*}{$\begin{array}{l}\text { Your "main" } \\
\text { source of } \\
\text { information } \\
\text { in } \\
\text { recognizing } \\
\text { the words } \\
\text { "jancuk", } \\
\text { "jancok", } \\
\text { "cuk", "cok" }\end{array}$} & \multirow{2}{*}{ Family } & 5 & 2 & 3 \\
\hline & & $4.1 \%$ & $1.7 \%$ & $2.5 \%$ \\
\hline & \multirow{2}{*}{$\begin{array}{l}\text { Friends/Friends/Neighbors around the } \\
\text { domicile }\end{array}$} & 68 & 41 & 27 \\
\hline & & $56.2 \%$ & $33.9 \%$ & $22.3 \%$ \\
\hline & \multirow{2}{*}{ Educational Environment } & 37 & 16 & 21 \\
\hline & & $30.6 \%$ & $13.2 \%$ & $17.4 \%$ \\
\hline & \multirow{2}{*}{ Work environment } & 4 & 1 & 3 \\
\hline & & $3.3 \%$ & $0.8 \%$ & $2.5 \%$ \\
\hline & \multirow{2}{*}{ Television } & 5 & 4 & 1 \\
\hline & & $4.1 \%$ & $3.3 \%$ & $0.8 \%$ \\
\hline & \multirow{2}{*}{ newspaper } & 1 & 0 & 1 \\
\hline & & $0.8 \%$ & $0.0 \%$ & $0.8 \%$ \\
\hline & \multirow{2}{*}{ Social media } & 1 & 1 & 0 \\
\hline & & $0.8 \%$ & $0.8 \%$ & $0.0 \%$ \\
\hline
\end{tabular}

Source: Results of the questionnaire (2021) 


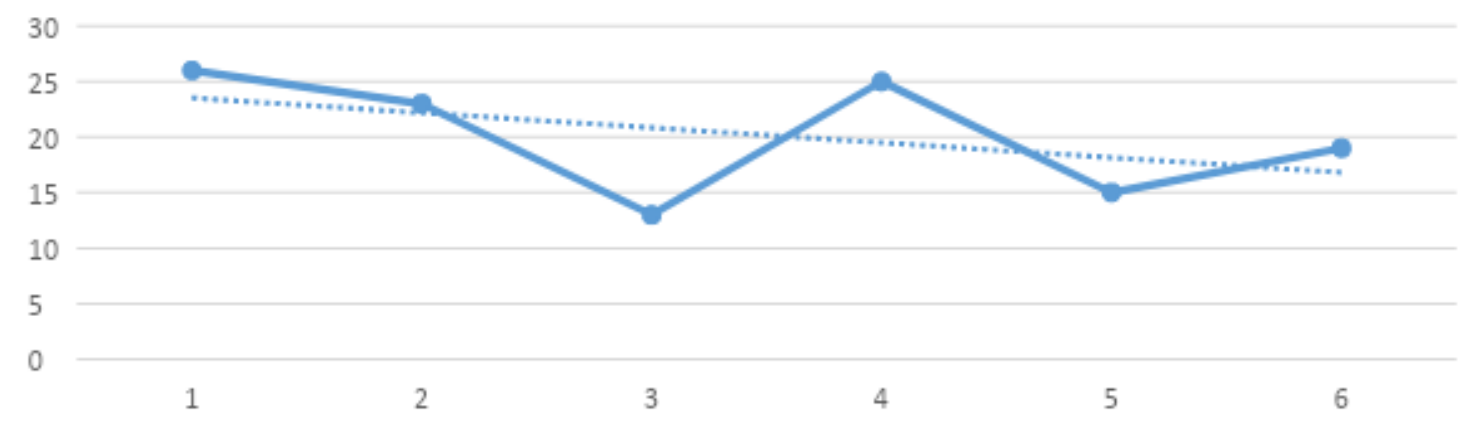

Source: Results of the questionnaire (2021)

Figure 2. The use of the words "jancuk", "jancok", "cuk", "cok" in conversation

Table 1 explains that as many as $53.7 \%$ of men and $46.3 \%$ of women claimed to have heard the words "Jancuk", "jancok", "choke", and "cok" in their daily lives. The age ranges of 21-30 years $(47.9 \%)$ and $31-40$ years $(43 \%)$ represent the age range of the general public who have come into contact with the word Jancuk. For education level, respondents with Bachelor's (62.8\%) and Postgraduate/Master (30.6\%) education levels prove that, indirectly, respondents will come into contact with the word Jancuk when they are in the educational environment. This is evidenced by the existence of educational environment variables (30.6\%) and friends/friends/neighbors around the domicile (56.2\%) are two of the main sources that support the main transfer of culture from the word Jancuk in people's lives. He added that the age range $<11$ years $(44.6 \%)$ and $11-20$ years $(37.2 \%)$ became the initial phase of the respondents when they heard the word jancuk. One of the impacts on the respondent's communication model in social activities is the use of the word Jancuk in daily activities. The results of this study explain that, most of them feel the interaction with the word jancuk also when they are in an educational environment and peers when they are in the school age range. However, according to Figure 2. as many as $51.2 \%$ of respondents tend to never apply the word jancuk in conversation. In fact, 21.

The word jancuk was implemented in the respondent's environment in childhood and was obtained from the educational environment as well as in friendship situations. The period of growing and being raised can make the respondent enter the word jancuk in the vocabulary of the respondent in social life. Some locations showing the distribution of the city or district area of the respondents are as follows,

\footnotetext{
${ }^{1}$ Note: questionnaire scores $(1=$ never; $6=$ often $)$
} 

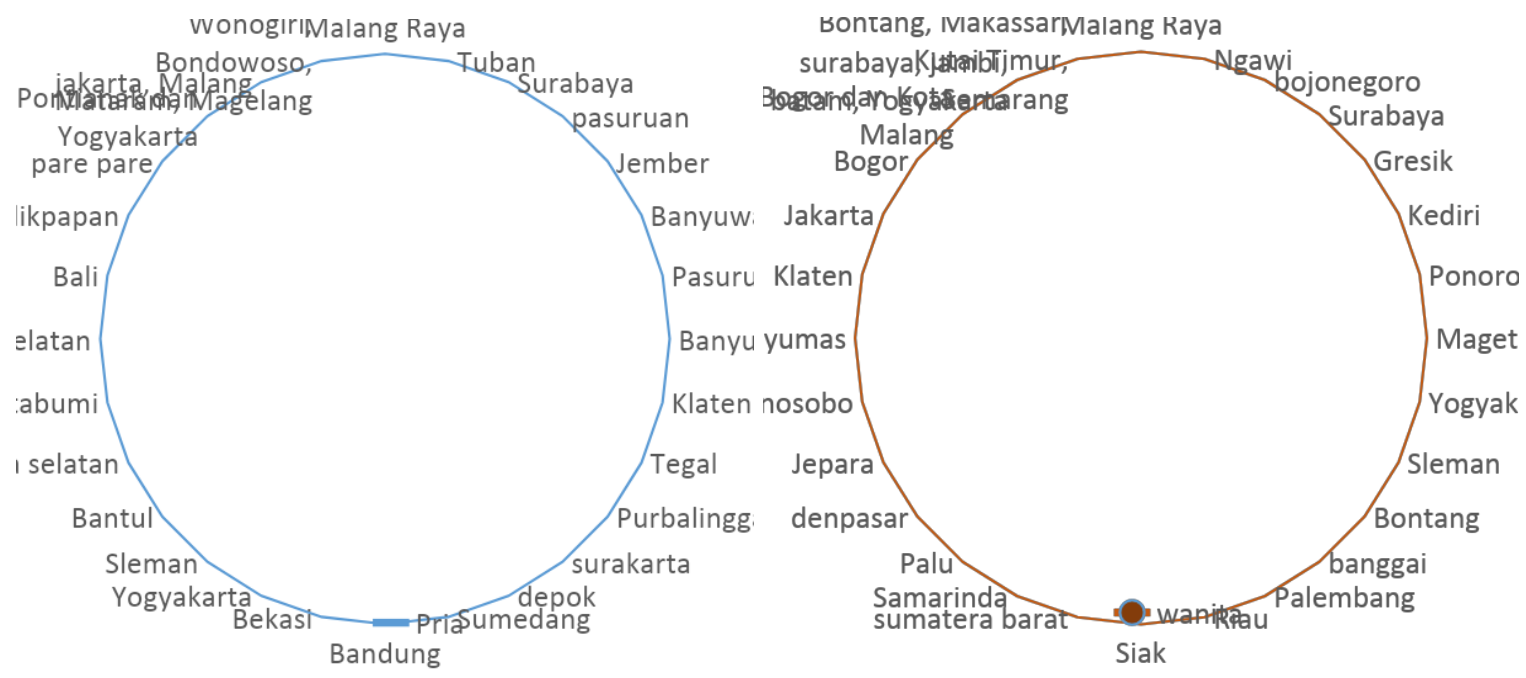

Source: Results of the questionnaire (2021)

Figure 3. Domicile Respondent's period of growth and upbringing (from baby to growing up (at the age of $0-17$ years))

Figure 3, shows that between male and female respondents who have their domicile grew and grew up spread across various regions in Indonesia. Most of them come from East Java such as Malang Raya, Tuban, Pasuruan, Jember, Banyuwangi, Ponorogo, Kediri, Surabaya, Bojonegoro, Magetan areas. From outside Java, there are areas such as Palembang, Siak, Bali, Bontang, Banggai, Denpasar, Palu, Balikpapan, Pontianak, Parepare, and so on. In addition, there were several respondents who experienced more than one place displacement during that period, such as (Wonogiri-Bondowoso-Mataram) or (Bontang-Makassar-East Kutai-Semarang).

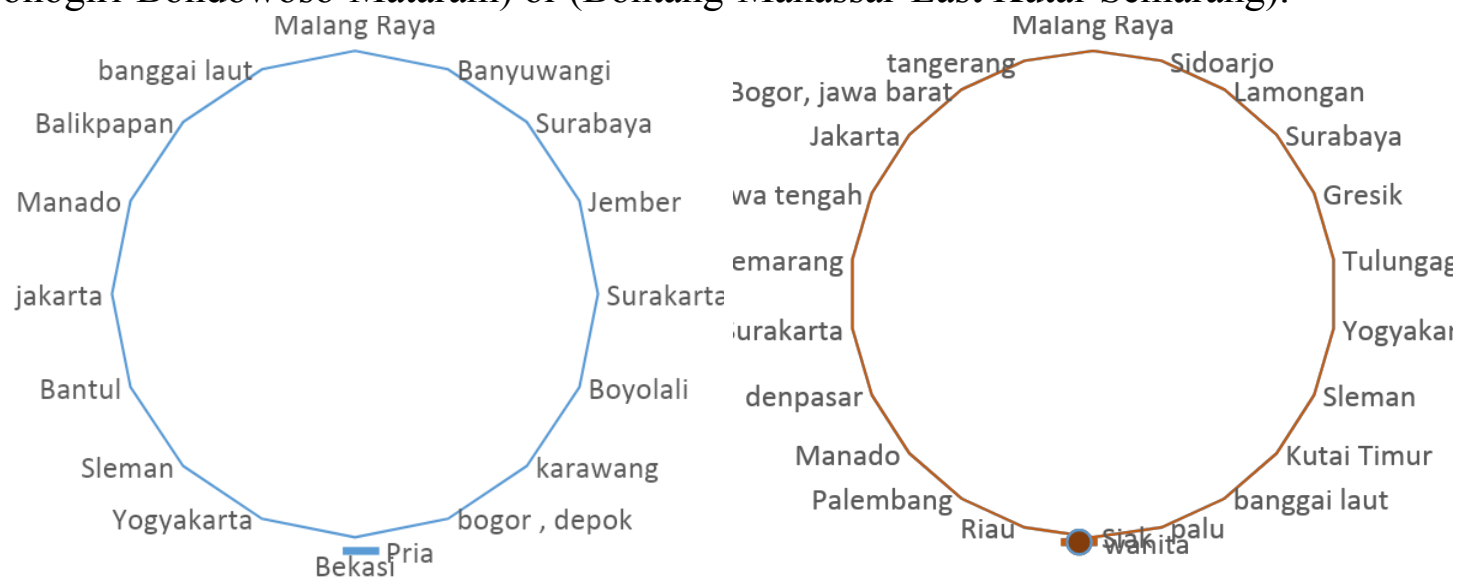

Source: Results of the questionnaire (2021)

Figure 4. Respondent's current domicile 
Furthermore, Figure 4 shows the current average domicile of the respondents. Most of them are spread to various areas on the island of Java. In addition to Malang Raya and Surabaya, there are overseas and industrial areas such as Jakarta, Yogyakarta, Balikpapan, Semarang, Manado, Palembang, to the sea, which is the current domicile of the respondents. Therefore, the difference in domicile when living with domicile when growing and growing up also shows the process of cultural transfer in society. Especially, when a person or group of people who have grown up in the arek cultural area apply the word jancuk in conversation at their current domicile.

The results of this study indicate that Jancuk's words are absorbed in the minds of respondents when they are studying and making friends, which are in the age range of under 11 years and 11 to 20 years. Indirectly, this will have an impact on the vocabulary that is likely to be used by respondents in conversation. Figure 2 . Shows that $48.8 \%$ actually tend to use the word jancuk in conversation. Where $15.7 \%$ of the respondents admitted that they often use the word jancuk in conversation. This shows that there is a transfer of culture through the word jancuk in the community. Cultural transfer implies, not just the transfer of a single object, and in essence, the inherent semantic and conceptual issues of the nation or cultural group involved.(Uribe \& Khalil, 2013). Therefore, Jancuk can be implied as a part of the identity of a cultural group. In this case what is meant is the arek culture from East Java. In the end, when respondents interact with people who apply the word Jancuk in their current domicile, it will produce a different perspective on the communicant. Perspectives related to the word jancuk will be able to bring up positive and negative values in the minds of the communicant.

\section{Perception of the word "jancuk", "jancok", "chock", "chock"}

Table 2. Perceptions of the words "jancuk", "jancok", "chock", "cok"

\begin{tabular}{|c|c|c|c|c|}
\hline \multirow[b]{2}{*}{ Variable } & \multicolumn{4}{|c|}{ Survey Results } \\
\hline & $\begin{array}{l}\text { Strongly } \\
\text { disagree }\end{array}$ & $\begin{array}{l}\text { Do not } \\
\text { agree }\end{array}$ & Agree & $\begin{array}{l}\text { Strongly } \\
\text { agree }\end{array}$ \\
\hline \multirow{2}{*}{ Has a negative value } & 15 & 50 & 46 & 10 \\
\hline & $12.4 \%$ & $41.3 \%$ & $38.0 \%$ & $8.3 \%$ \\
\hline \multirow{2}{*}{$\begin{array}{c}\text { considered as part of language as an impolite } \\
\text { word }\end{array}$} & 9 & 34 & 51 & 27 \\
\hline & $7.4 \%$ & $28.1 \%$ & $42.1 \%$ & $22.3 \%$ \\
\hline \multirow{2}{*}{ Is a word that comes from East Java } & 2 & 4 & 20 & 95 \\
\hline & $1.7 \%$ & $3.3 \%$ & $16.5 \%$ & $78.5 \%$ \\
\hline \multirow{2}{*}{ is part of the language culture } & 8 & 22 & 44 & 47 \\
\hline & $6.6 \%$ & $18.2 \%$ & $36.4 \%$ & $38.8 \%$ \\
\hline \multirow{2}{*}{$\begin{array}{l}\text { when heard around you will disturb the } \\
\text { feeling }\end{array}$} & 28 & 59 & 24 & 10 \\
\hline & $23.1 \%$ & $48.8 \%$ & $19.8 \%$ & $8.3 \%$ \\
\hline \multirow{2}{*}{ makes you offended when spoken to you } & 23 & 58 & 28 & 12 \\
\hline & $19.0 \%$ & $47.9 \%$ & $23.1 \%$ & $9.9 \%$ \\
\hline
\end{tabular}


Will reduce the value of politeness / manners of someone who pronounces it

Source: Results of the questionnaire (2021)

In general, jancuk", "jancok", "choke", or "cok" are part of pisuhan or swearing. Swearing has a meaning that is not much different from swear words, namely vile or dirty words spoken out of anger, irritation or disappointment. For example, "Jiancuk, your behavior is like the devil, you don't know the rules!" expresses the word jiancuk which means 'coitus' or committing indecent acts (Sudarmaningtyas, 2020). This study tries to reveal the perception related to the word jancuk with its various variations from the point of view of the general public. Table 2 describes the various perceptions of jancuk, "jancok", "cuk", or "cok" from the general public in Indonesia. The results of this study indicate that most respondents tend to disagree if Jancuk is considered to have a negative value (41.3\% TS, $12.4 \%$ TS). However, the word jancuk still tends to be considered as part of the language as an impolite word ( $42.1 \% \mathrm{~S}, 22.3 \% \mathrm{SS})$.

In relation to the origin of the word jancuk, most of the respondents agreed $(16.5 \% \mathrm{~S}, 78.5 \%$ SS) that jancuk is a word that comes from East Java. Even though it is considered a language that violates the rules of etiquette and politeness in East Java, Jancuk is still considered a word that has less negative value. This is confirmed by the assumption that jancuk is part of the language culture of the majority of respondents $(36.4 \% \mathrm{~S}, 38.8 \% \mathrm{SS})$. In one of its applications in conversation, jancuk has become part of the most communicative Suroboyoan language.(Sriyanto \& Fauzie, 2017). Therefore, the word jancuk has become a part of the communication process in culture, especially Surabaya arek culture. Jancuk is part of the culture that has had various impacts on the respondents. Indirectly, when the word jancuk is heard around the respondents, most of the respondents do not agree to consider it a nuisance $(23.1 \%$ STS, $48.8 \%$ TS). Then, if spoken to the respondent directly, it is also not considered part of the offence (19.0\% STS, $47.9 \%$ TS). This explains that respondents think that the word jancuk is not too disturbing. However, this needs to pay attention to several components in the communication model that is carried out. the use of the word jancuk in communication behavior, pay attention to several things, including the following: voice intonation, facial appearance,(Sriyanto \& Fauzie, 2017). Therefore, more reasoning is needed when someone interprets the word jancuk spoken by someone.

Outside the components in the communication model process, there are emotions that are released when the word jancuk appears in conversation. The word jancuk that is issued depends on the emotions released by the interlocutor and the environment around the respondent. Emotions are complex reactions that contain a high degree of activity and physical changes, and are associated with strong feelings(Walgito, 2010). Added to that, emotions are more intense 
than feelings, and often changes in behavior, relationships with the environment are sometimes disturbed. This is what causes the word jancuk to interfere with direct feelings and cause offense indirectly depending on the emotional situation of the communicant. In the end, the word jancuk that is spoken will reduce the value of one's politeness and manners. This is agreed by most of the respondents $(41.3 \% \mathrm{~S}, 24.0 \% \mathrm{SS})$. This is because in social reality, the use of the word jancuk will be followed by paralanguage with tone, emphasis, and volume, such as loud, loud, the emphasis is steady, and seems like someone screaming.(Sriyanto \& Fauzie, 2017). Thus, more understanding is needed of the meaning of jancuk as a part of culture. Where in fact jancuk has been considered a deducting variable on the value of manners and politeness.

\section{The meaning of the words "jancuk", "jancok", "choke", "chock"}

Table 3. The meaning of the words "jancuk", "jancok", "cuk", "cok"

\begin{tabular}{|c|c|c|c|c|}
\hline \multirow[b]{2}{*}{ Variable } & \multicolumn{4}{|c|}{ Survey Results } \\
\hline & $\begin{array}{l}\text { Strongly } \\
\text { disagree }\end{array}$ & $\begin{array}{c}\text { Do not } \\
\text { agree }\end{array}$ & Agree & $\begin{array}{c}\text { Strongly } \\
\text { agree }\end{array}$ \\
\hline \multirow{2}{*}{ angry feeling } & 7 & 54 & 40 & 20 \\
\hline & $5.8 \%$ & $44.6 \%$ & $33.1 \%$ & $16.5 \%$ \\
\hline \multirow{2}{*}{ annoyance towards someone/something } & 4 & 34 & 53 & 30 \\
\hline & $3.3 \%$ & $28.1 \%$ & $43.8 \%$ & $24.8 \%$ \\
\hline \multirow{2}{*}{ someone's regret } & 15 & 36 & 50 & 20 \\
\hline & $12.4 \%$ & $29.8 \%$ & $41.3 \%$ & $16.5 \%$ \\
\hline \multirow{2}{*}{ sadness } & 31 & 39 & 36 & 15 \\
\hline & $25.6 \%$ & $32.2 \%$ & $29.8 \%$ & $12.4 \%$ \\
\hline \multirow{2}{*}{ disappointment with someone/something } & 1 & 35 & 50 & 35 \\
\hline & $0.8 \%$ & $28.9 \%$ & $41.3 \%$ & $28.9 \%$ \\
\hline \multirow{2}{*}{ admiration for someone/something } & 18 & 31 & 44 & 28 \\
\hline & $14.9 \%$ & $25.6 \%$ & $36.4 \%$ & $23.1 \%$ \\
\hline \multirow{2}{*}{ an expression to insult someone/something } & 12 & 32 & 42 & 35 \\
\hline & $9.9 \%$ & $26.4 \%$ & $34.7 \%$ & $28.9 \%$ \\
\hline \multirow{2}{*}{ expression of surprise } & 5 & 24 & 52 & 40 \\
\hline & $4.1 \%$ & $19.8 \%$ & $43.0 \%$ & $33.1 \%$ \\
\hline \multirow{2}{*}{ a symbol of familiarity or a sense of humor } & 2 & 17 & 34 & 68 \\
\hline & $1.7 \%$ & $14.0 \%$ & $28.1 \%$ & $56.2 \%$ \\
\hline \multirow{2}{*}{ happy expression } & 15 & 43 & 34 & 29 \\
\hline & $12.4 \%$ & $35.5 \%$ & $28.1 \%$ & $24.0 \%$ \\
\hline
\end{tabular}

Source: Results of the questionnaire (2021)

Perceptions related to jancuk have shown the respondent's point of view in arek cultural communication from various domiciles. Table 3 explains the various meanings of jancuk from respondents who represent the general public in Indonesia. The results of this study indicate several variables that tend to be agreed upon as important meanings of the word jancuk such as, 
expressions to insult someone/something (63\%), annoyance towards someone/something (68.6\%), disappointment with someone/something (70.2\%), expressions of surprise (76\%), and symbols of intimacy or a sense of humor (84.3\%). Although it is perceived that it will reduce the value of politeness or manners, most respondents interpret jancuk as a symbol of intimacy or a sense of humor. The word cuk / jancuk is a variation of the type of language "slang",(Budiman et al., 2018). Added according to Tejo (2012) inKhotimah (2019), namely:

"Jancuk is like a knife. The function of the knife is very dependent on the user and the psychological atmosphere of the user. If used by criminals, it could be a murder weapon. If used by a wife who is devoted to her family, it can be a cooking tool. Likewise, if jancuk is spoken with insincere intentions, full of anger and revenge, it will be able to hurt. However, when spoken with the will of intimacy, the will is warm as well as fluid in gathering associations."

In addition, there are other variables that are not agreed upon such as the meaning of the word jancuknamely, feelings of sadness (49.6\%) and feelings of anger (42.1\%). This is contrary to opinionSriyanto \& Fauzie (2017), where jancuk can also be used to swear at someone, it can also be an expression of anger from someone to someone who is really angry. Eventually,Jancuk as a word apartor curses are not only questioned in their use when expressing anger. However, swear words can be spoken by anyone, anytime, and anywhere(Nurdiyanto, 2018). Therefore, the meaning of the person who hears the word jancuk will be different between one another depending on the perception of each communicant.

\section{CLOSING}

Jancok can be applied in the pronunciation of other words such as jancok, cuk, or cok. Jancuk who has become a part of pisuhan or curses in arek culture from East Java. The results of this study indicate that, most people get the word jancuk when they grow up and take education. This phase occurs when the community is in the arek cultural area of East Java. The use of jancuk tends not to be perceived as negative because it depends on the intensity of emotion in one's communication model. In addition, the word jancuk is generally considered to violate manners in the communication process. This depends on the use of the word jancuk in the conversation of a communicator. So, someone needs to adjust the tone, emphasis, and volume of speech when applying the word jancuk in conversation.

The word jancuk tends to be agreed upon in several important meanings, such as: expressions of contempt, annoyance, disappointment, surprise, and symbols of intimacy or a sense of humor. As a pisuhan, jancuk is not only used at a certain emotional level. Jancuk can be spoken by anyone, anytime, and anywhere depending on the meaning received by the 
communicant. This research can be used as a reference material in the next research that tries to uncover other separate concepts. Therefore, jancuk can be expressed as an important material in the process of cultural communication. Where jancuk has been able to become an invisible intermediary who is able to show its own value in society. Jancuk originating from arek culture has been able to show the diversity of words from each region which will enrich the process of cultural transfer that occurs in society. This research is expected to provide justification for the community that jancuk can be an important contributor in the process of enriching intercultural communication materials in society.

\section{REFERENCES}

Abdillah, A. (2007). Arek Suroboyo culture, a study of the beginning of its existence through the context of social change in the Surabaya village community (Thesis). Airlangga University, Surabaya.

Bachri, BS (2010). Ensuring Data Validity Through Triangulation In Qualitative Research. Journal of Educational Technology, 10, 46-62.

Budiman, A., Sujinah, S., \& Ngatma'in, N. (2018). Social Deixis Collection of Republic Book Essays \#Jancukers by Sujiwo Tejo. 9(2), 80-100. http://journal.um-surabaya.ac.id/index.php/Stilistika/article/view/1177/859\%0Ahttp://journa l.um-surabaya.ac.id/index.php/Stilistika/article/ download/1177/859\%0Ahttps://lens.org/053-977-427-219-856

Jannah, A., Widayati, W., \& Kusmiyati, K. (2018). Forms and Meanings of swear words at the Purabaya Terminal Surabaya in a Sociolinguistic Study. Phonemes, 4(2), 43-59. https://doi.org/10.25139/fonema.v4i2.758

Khotimah, N. (2019). Satire Analysis on Sujiwo Tejo's Twitter and Instagram Status in the Perspective of Da'wah Communication. UIN Walisongo Semarang.

Nurdiyanto, E. (2018). The Meaning of Indonesian Words That Can Contain Elements of Swearing. Proceedings of the National Seminar and Call for Papers "Sustainable Development of Rural Resources and Local Wisdom VIII" 14-15 November 2018 Purwokerto, November, 140-152.

Pani, EL (2019). The Influence of Customer Perception, Perceived Value, Price and Promotion on Buying Decisions on Lion Air Tickets. Agora, 7(2), 287119.

Sihwanti, N. (2019). The Effect of Intercultural Communication on Social Integration in the Javanese-Chinese Ethnic in Sudiroprajan Village. Muhammadiyah Surakarta university.

Soecahyadi. (2012). Statistical Analysis with SPSS (1st ed., April issue). Sahid University Jakarta.

Somantri, GR (2005). Gumilar Rusliwa Somantri. Makara, Social Humanities, 9(2), 57-65. https://media.neliti.com/media/publications/4388-ID-memahami-method-kualitatif.pdf

Sriyanto, S., \& Fauzie, A. (2017). the use of the word "Jancuk" as a cultural expression in Arek's 
Communication Behavior in Kampung Surabaya City. Journal of Theoretical Psychology Dan T, 7(2), 88-102.

Statistics of East Java Province. (2021). Jawa Timur Province in Figure 2021 (Division of Integration Processing and Statistics Dissemination (ed.)). BPS-Statistics of East Java Province.

Sudarmaningtyas, AER (2020). Pisuhan Javanese Language Play in the Strategy of Improving Identity and Communication Ethics in Javanese Society. The Humanities And The Era Of Technological Disruption In A Historical Context, 1(1), 320-331. https://jurnal.ac.id/index.php/prosiding/issue/view/1031

Sungkowati, Y. (2019). Arek Culture In Literary Works. Journal International Seminar on Languages, Literature, Arts, and Education, 1(1), 165-170.

Uribe, AA, \& Khalil, LMG (2013). The concept of cultural transfers and reflections about Brazilian versions of English-language rock songs. Revista Dialogos, 1(10), 72-94. https://doi.org/10.13115/2236-1499.2013v1n10p72

Walgito, B. (2010). Introduction to General Psychology (Ed. IV). ANDI Yogyakarta.

Winiasih, T. (2012). Pisuhan in "Basa Suroboyoan" Sociolinguistic Studies. Sebelas Maret University.

Wiratno, T., \& Santosa, R. (2014). Language, Language Functions, and Social Context. Introduction to General Linguistics $\quad$ Module, 1-19. http://www.library.ut.ac.id/lib/wp-content/uploads/pdfmk/BING4214-M1.pdf

Zellatifanny, CM, \& Mudjiyanto, B. (2018). Types of Research Descriptions in Communication Studies. Diakom : Journal of Media and Communication, 1(2), 83-90. https://doi.org/10.17933/diakom.v1i2.20 